\title{
How Do the Approaches to Accountability Compare for Charities Working in International Development?
}

\author{
À quel point les mécanismes de l'obligation \\ de rendre compte dans les organismes de \\ bienfaisance qui œuvrent au développement \\ international sont-ils comparables?
}

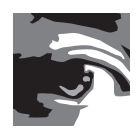

DAVID KIRSCH, MHSC, PHD

Research Fellow, Global Health Diplomacy Program

Munk School of Global Affairs, University of Toronto

Toronto, ON

\begin{abstract}
Approaches to accountability vary between charities working to reduce under-five mortality in underdeveloped countries, and healthcare workers and facilities in Canada. Comparison reveals key differences, similarities and trade-offs. For example, while health professionals are governed by legislation and healthcare facilities have a de facto obligation to be accredited, charities and other international organizations are not subject to mandatory international laws or guidelines or to de facto international standards. Charities have policy goals similar to those found in the Canadian substudies, including access, quality, cost control, cost-effectiveness and customer satisfaction. However, the relative absence of external policy tools means that these goals may not be realized. Accountability can be beneficial, but too much or the wrong kind of accountability can divert resources and diminish returns.
\end{abstract}

\section{Résumé}

Les mécanismes de l'obligation de rendre compte varient entre, d'un côté, les organismes de bienfaisance qui travaillent pour réduire la mortalité des enfants de moins de cinq ans dans les pays sous-développés et, de l'autre, les travailleurs et les établissements de services de santé au Canada. Une comparaison révèle d'importantes différences, similitudes et mécanismes de 
substitutions. Par exemple, alors que les professionnels de la santé sont gouvernés par des lois et que les établissements de santé ont l'obligation de facto d'obtenir leur agrément, les organismes de bienfaisance et autres organisations internationales ne sont pas assujettis à des lois ou directives internationales obligatoires, ou à d'autres normes internationales de facto. Les organismes de bienfaisance ont des objectifs semblables à ceux des établissements canadiens qui ont fait l'objet de l'étude, notamment, l'accès, la qualité, le contrôle des coûts, le rapport coût-efficacité et la satisfaction des clients. Cependant, l'absence relative d'outils de politique externes met en péril l'atteinte de ces objectifs. L'obligation de rendre compte peut être avantageuse, mais une obligation trop exigeante ou erronée peut dévier les ressources et en diminuer les retombées.

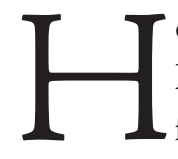

OW applicable are the findings of This Study to other Settings?

My work examining accountability in various charities working to reduce under-

five mortality in developing countries (Kirsch 2013) suggests that there are key differences and similarities that highlight the importance of the existing structures and how they influence the ability to use various policy instruments. Like this study, my work considered the "for what, to whom and why" of accountability, and also looked at the effects of accountability and variations based on size and other organizational characteristics.

One key difference relates to the differences between who is delivering care and how care is funded. Although reductions in under-five mortality rates are one of the United Nations' Millennium Development Goals (MDGs), the vehicle for accomplishing this is usually through non-governmental organizations (NGOs), defined as formal, self-governing organizations that are separate from governments and hence have no ability to direct societies or require support from them, and also are not in the business of making or distributing profits (Gordenker and Weiss 1996). For tax purposes, Canadian NGOs are incorporated as charities, and the terms NGO and charity are used interchangeably in this commentary.

The Government of Canada (GOC) does not work directly to reduce under-five mortality in developing countries, but rather provides funding to organizations, such as the Canadian International Development Agency (CIDA), which in turn directs funding to NGOs. The GOC also provides tax incentives for taxpayers who donate funds to charities. Given this chain of delegation, the "to whom" element can be complex; NGOs may be expected to be accountable to various combinations of those who fund charities (both governments and private donors), those whom they help, those who are interested in or indirectly affected by what they do and those with whom they work (Christensen and Ebrahim 2006). With few exceptions, accountability for charities is not strongly regulated within Canada; depending on the country, charities frequently have few legal requirements to be accountable in the countries where they work. Depending on the sources of funding, however, charities may have strict contractual obligations to provide predefined accountability reports to major funders. 
The substudies described in this Special Issue concentrated on four policy instruments: financial incentives, regulations, information directed towards patients/payers and professionalism/stewardship. The enforcement mechanisms thus can include provision of information, licensure/accreditation, payment, legal sanctions or some combination of these. In contrast to the Canadian examples, whereby healthcare professionals are governed by legislation and healthcare facilities have a de facto obligation to be accredited, charities and other organizations that work internationally are not subject to mandatory international laws or guidelines, or de facto international standards. Although these policy instruments are not always available in international charitable settings, organizations such as the Red Cross, Humanitarian Accountability Partnership and the Philippine Council for NGO Certification have developed standards for conduct, accountability and accreditation. However, these organizations do not have any legislative power to force charities to join their organizations, or to stop the charities or their staff from conducting programs or providing services, even if they do not meet these standards; at most, they can stop the charities from using the association's logo. To further complicate the situation, a staff member who is terminated with cause from one charity can go to work at another charity: privacy laws may even restrict a charity from providing a bad reference. Similarly, health professionals from Ontario and other jurisdictions who work overseas for NGOs are not subject to the same scrutiny overseas as they are in their own jurisdictions.

NGOs have similar policy goals to those found in the Canadian substudies, including access, quality, cost control, cost-effectiveness and customer satisfaction. However, there is a relative absence of external policy tools to ensure that these goals are realized. The key tool appeared to be information/exhortation. In order to ensure a donation stream, charities have traditionally provided information about their good works and high-level information about their programs and administrative costs. In lieu of extensive accountability reporting, the literature suggests that the public has evaluated charities based on mission statements, annual fundraising and administrative expenses, and the perceived quality of the brand. People generally give because they believe in the vision and trust or hope that the charities will eventually succeed (Aldashev and Verdier 2010; Waters 2008). Governments also subsidize these private donations to charities, to the extent that taxpayers can use tax donation receipts to reduce their taxable income. Although administrative costs are not applied consistently across the sector (Wenar 2006), the ratio of money spent on administrative costs to money raised is often used as a proxy for effectiveness (Walsh and Lenihan 2006). Sargeant (1999) notes that, while people do not necessarily believe the ratios, they often continue to support the charities.

NGOs can also be funded by corporations, development banks, governments, high-networth individuals and others in a position to demand accountability through evaluations and other means. However, the literature contains mixed reviews of evaluations (Doucouliagos and Paldam 2006), and some literature suggests that rather than enhancing accountability and improving effectiveness, evaluations have created incentives for deception (Bornstein 2006; Hager 2005). Fortunately, stewardship and professionalism play an important role in ensuring that many NGOs do not yield to these temptations. Although many of those working for 
NGOs are volunteers, they (and the paid staff) typically have strong beliefs in the vision and mission of their organizations and wish to act in a professional manner. These internal, external and financial pressures can be beneficial, especially when they encourage learning.

However, should that trust be seen as unwarranted, NGOs may see a reduction in their donation/funding stream due to lack of trust or violations of their funding agreements with major funders. In practice, larger charities do tend to follow the standards of various standards groups and work together to improve accountability in the sector. As in this study, answerability may lead to attempts to censure, shame and blame those who are deemed to be accountable, but these tactics are limited to the confines of the individual charities.

My study found that with strong regulation, accountability can lead to better care, better efficiency in use of resources and improved outcomes. It noted that if accountability was poorly implemented, it could result in excessive expenditure of resources and potential loss of support. The charities were asked for the reasons driving their accountability; they said that they were most likely to be accountable because accountability was perceived to be a good management practice that improved program effectiveness while reducing risk, and least likely to be accountable because it was a standards body, legal or accreditation requirement. Charities were also accountable because of the contractual obligations of funders. In the absence of strong regulation, my study further found that charities are most accountable to their boards of directors, staff and management teams and least accountable to peers, community groups, the general public and beneficiaries.

Charities can be accountable because of external or internal pressures. We found that being accountable because of external pressures often equates to being accountable in order to comply with an external requirement, while being accountable because of internal pressures can equate to either complying or learning, depending on the policies established by the charities' management. The accountability information that funders demand certainly fits as a compliance requirement while, depending on the details, the information may also provide a learning opportunity for charities.

One positive unintended consequence is that, as accountability information becomes more readily available internally, it becomes easier to share externally. My study found that the amount and type of information that charities are willing to share varied by accountability mechanism and, to a lesser extent, by the size of the charity. In general, the survey data showed that charities were more willing to be accountable for learning from successes than they are for their failures. Keohane (2003) notes that successes lead to improved reputation, which gives charities the incentive to report on their successes. Another similarity to the results in the Canadian substudies is that size matters; among the NGOs studied, the existence of accountability mechanisms within charities tended to increase with charity size and there was a much greater difference in their use between small and medium charities than there was between medium and large charities (size was categorized based on annual budgets).

Increased accountability to peers, a group that was very low on the accountability lists of all charities, could help charities learn from the mistakes of the past and ensure that they are not repeated in the future, especially when such reports are published for all to review. 
How Do the Approaches to Accountability Differ for Charities

Working in International Development?

This concept is embodied in the requirements of various standards bodies and international initiatives, but reality must be aligned with the rhetoric for any positive effects to be realized. As noted, there are fewer consequences for NGOs than for the organizations studied in the Canadian examples reported in this special issue.

Although financial consequences did play a role in all of these studies, they also operate somewhat differently among NGOs. In particular, the desire to maintain trust means that accountability information is directed to donors/major funders but not necessarily to beneficiaries, who typically have less power to demand accountability. Devising mechanisms to involve beneficiaries in the process would still seem advisable, however, because other research has found that this leads to better quality of services and improved outcomes (Wenar 2006).

In conclusion, it is striking that similar trade-offs/balances were found in both studies. Accountability can be beneficial, but too much or the wrong kind of accountability can divert resources and diminish returns. However, the absence of consequences can also leave meeting goals to the good will of the NGOs, which may or may not be sufficient.

Correspondence may be directed to: David Kirsch, PhD, Research Fellow, Global Health Diplomacy Program, Munk School of Global Affairs, University of Toronto, 1 Devonshire Place, Toronto, ON M5S 3K7; tel.: 416-967-1660; e-mail:david.kirsch@utoronto.ca.

\section{References}

Aldashev, G. and T. Verdier. 2010. “Goodwill Bazaar: NGO Competition and Giving to Development.” Journal of Development Economics 91(1): 48-63.

Bornstein, L. 2006. "Systems of Accountability, Webs of Deceit? Monitoring and Evaluation in South African NGOs." Development 49(2): 52-61.

Christensen, R.A. and A. Ebrahim. 2006. "How Does Accountability Affect Mission? The Case of a Nonprofit Serving Immigrants and Refugees." Nonprofit Management and Leadership 17(2): 185-209.

Doucouliagos, H. and M. Paldam. 2006. "Aid Effectiveness on Accumulation: A Meta Study." Kyklos 59(2): 227-54. Gordenker, L. and T.G. Weiss. 1996. "Pluralizing Global Governance: Analytical Approaches and Dimensions." In L. Gordenker and T.G. Weiss, eds., NGOs, the UN and Global Governance. Boulder, CO: Lynne Rienner Publishers. Hager, M. 2005 (February 1). Nonprofit Disclosure: The Answer to Accountability? Forum comments, Forum on Nonprofit Disclosure, Urban Institute. Retrieved March 25, 2014. <http://www.urban.org/url.cfm?ID=900780\& renderforprint $=1>$.

Keohane, R.O. 2003. "Global Governance and Democratic Accountability." In D. Held and A.M. KeonigArchibugi, eds., Taming Globalization: Frontiers of Governance. Cambridge, UK: Polity Press. Retrieved March 25, 2014. <http://unpan1.un.org/intradoc/groups/public/documents/apcity/unpan034133.pdf>.

Kirsch, D.C. 2013. Accountability in Children's Development Organizations. PhD dissertation, University of Toronto, Toronto. Retrieved March 25, 2014. <http://hdl.handle.net/1807/35865>.

Sargeant, A. 1999. "Charitable Giving: Towards a Model of Donor Behaviour." Journal of Marketing Management 15(4): 215-38.

Walsh, E. and H. Lenihan. 2006. "Accountability and Effectiveness of NGOs: Adapting Business Tools Successfully." Development in Practice 16(5): 412-24.

Waters, R.D. 2008. "Applying Relationship Management Theory to the Fundraising Process for Individual Donors." Journal of Communication Management 12(1): 73-87.

Wenar, L. 2006. "Accountability in International Development Aid." Ethics and International Affairs 20(1): 1-23. 